\title{
THE COMPARISON QUESTION SENTENCES BETWEEN KARONESE AND ENGLISH LANGUAGE: TEORY X-BAR
}

\author{
Sri Ninta Tarigan ${ }^{1}$, Mulyadi $^{2}$ \\ srinintatarigan@unprimdn.ac.id \\ Universitas Sumatera Utara- Indonesia
}

\begin{abstract}
The objective of this study is to find the comparison question sentences between Karonese and English language. The method of this study was Chomsky Theory $\mathrm{X}$ bar to discussed the syntax and semantic writes a diagram tree and NP, VP, PP, AP, Adv.P in questions in sentences. It showed that the dominant questions sentences in Karonese use; Wh-Q + NP? It wrriten 15 times sentences in question. The second position was Wh-Q $+\mathrm{NP}+\mathrm{C}$. English has tenses to mention something. It would be different auxiliary when the time in the present, past and future. The second was found that most English questions have the same formula when asking something. The formula used Wh-Q + Aux $+S+V+C$ ? It conclude that there were a different way to arrange questions sentence in Karonese and English language.
\end{abstract}

Keywords: Comparison, Karonese, English, Language, X-Bar

\section{INTRODUCTION}

This research discussed about the comparison question sentences between Karonese and English language. Here the writer tried to find the grammatical question in Karonese and English. As the references the writer also tried to find previous study that discussed about the topic, but there was a little researchers that have observed this research. The first researcher was Fitriani dan Mulyadi (2017). They discussed about Minagkabau Sentences. They found that For wh-question, the question words (sia, apo, dima, kama, bilo, manga, baa, and bara) has two syntactic representations depending on their position in the sentence. The first representation is as specifier, when it is placed in the front position. The second representation is as complement, when it is as a complement. The second researcher was Revita (2007). She also observed Minagkabau sentence. Her research finding was Minagkabau sentences constructed by declarative, introgative and exclamative.

Aqad (2013) on his research "Syantactic Analysis of Arabic Adverb's between Arabic and English: X bar Theory" was found that The results of this study found that applying X-bar theory on Arabic sentences shown changeable positions of adverbs between Arabic and English. Also, it shows the subject position of Arabic in X-bar theory which is initially. Arabic language has a lot of transferable constituents. In this paper, the order of the sentences easily changes from SVO to other states. The applications of $\mathrm{X}$ bar theory on Arabic language sentences show the differences and indiscernible constituents structures among languages. The previous researchers has observed the sentence in Minagkabau and Arab language and they have found the result finding. Their result finding would be aa refernces for the writer to observe the comparison between Karonese and English language with X-Bar Theory. There have not Karonese conducted this research before was a backgroud for the writer to discuss this study.

Here the examples of phrase according to Haegeman (1992).

Writing a letter $(\mathrm{FV})$

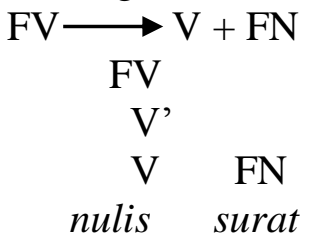

Beautiful doll

$\mathrm{FA} \longrightarrow \mathrm{N}+\mathrm{FA}$

FN

N'

$\mathrm{N} \quad \mathrm{FA}$

Boneka simejile

NICCT 2019, September 20-21, Medan, Indonesia

Copyright (C) 2020 EAI

DOI 10.4108/eai.10-6-2020.165508 
writing letter

Beautiful doll

To support this phrase that has given from Haegeman (1992) so Newson (2006:87) tried to explain the phrase in sentences. The examples of phrase in sentences is He Speaks to $m e$. So the teori X-Bar in sentence can be describe as below:

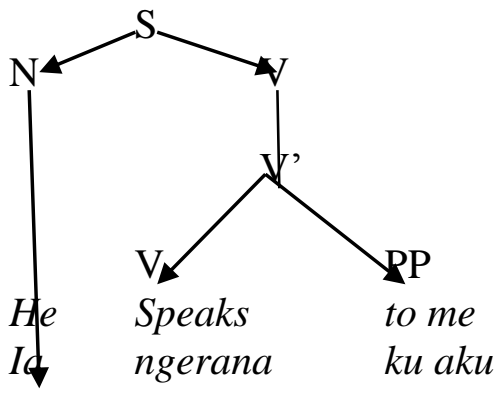

\section{RESEARCH METHOD}

This research use Chomsky Teory $\mathrm{X}$ bar to discussed the syntac and semantic with draw a diagram tree and NP, VP, PP, AP, Adv.P in questions in sentences. It would be explain the sentences in Karonese and English language. This research would be describe the Wh-Question, NP, VP, PP, Complement in Karonese and English language. There some steps used to collecting the data. First the writer collected the Karonese language and comphare to the English language.

\section{RESULT FINDING AND DISCUSSION}

a. Wh-Q in Karonese and English Language

Karonese language has also Wh-Question dand Yes-No Question. Below the questions.

Tabel.1 The Comrehending Wh-Question Between Karonese and English Langugae

\begin{tabular}{|l|l|l|}
\hline No. & $\begin{array}{l}\text { Wh-Question } \\
\text { In Karonese Language }\end{array}$ & $\begin{array}{l}\text { Wh-Question } \\
\text { In English }\end{array}$ \\
\hline 1. & Ise dilaki si make baju megara ah? & Who is the man with the red shirt? \\
\hline 2. & Ise gelar diberu ena? & What is the girl's name? \\
\hline 3. & Ise si pang ngelawan Singa ena? & Who braves to fight with the lion? \\
\hline 4. & Ise si pegeluh lampu ena? & Who turns the light? \\
\hline 5. & Ise si nukur tipi enda? & Who buys the Television? \\
\hline 6. & Ise si erdalan ras nande ndai? & Who walks with mother? \\
\hline 7. & Ise gelarndu? & What is your name? \\
\hline 8. & Ise temanndu ku jenda? & Who is your friend to come here? \\
\hline 9. & Ise gelar nandendu? & What is your mother name? \\
\hline 10. & Ise si nokohi kam? & Who lies with you? \\
\hline 11. & Ise sitading ndeher rumahndu ena kak? & Who is the person live near your house? \\
\hline 12. & Ise gundari si tading i jenda? & Who is living here? \\
\hline 13. & Ise gelar diberu si mejile ena? & What is the beatiful girl name? \\
\hline 14. & Ise nge sipuna rumah mejile enda? & Whose house is it? \\
\hline
\end{tabular}




\begin{tabular}{|c|c|c|}
\hline 15. & Ise nge danci ngapuli kita? & Who can give us wise word? \\
\hline 16. & $\begin{array}{l}\text { Ise si jadi pemenang na i bas pertandingen } \\
\text { ndai? }\end{array}$ & Who is the winner? \\
\hline 17. & Ise ena nak ku? & Who is he? \\
\hline 18. & Sora ise ena? & Whose sounds it? \\
\hline 19. & Ise si danci nampati aku enda nake? & Who could help me? \\
\hline 20. & Ise si mbaru reh ena? & Who does just arrive? \\
\hline 21 & Ndigan kam mulih? & When will you come home? \\
\hline 22 & Ndigan kam reh? & When do you come? \\
\hline 23 & Ndigan kam sereh? & When do you come? \\
\hline 24 & Ndigan ia empo? & When will you marry? \\
\hline 25 & Ndigan ia pasu-pasu? & $\begin{array}{l}\text { When she/he will be blessed of her/his } \\
\text { married? }\end{array}$ \\
\hline 26 & Ndigan kam lawes? & When will you go? \\
\hline 27 & Ndigan tasakken gulen ena? & When the curry will be cooked? \\
\hline 28 & Ndigan kerja tahun kutandu? & $\begin{array}{l}\text { When a thanksgiving will be held in } \\
\text { your hometown? }\end{array}$ \\
\hline 29 & Ndigan nge buniken Bp. Sope ndai? & When will be the corpse burried? \\
\hline 30 & Ndigan i benai acara enda? & When will be event started? \\
\hline 31 & Ndigan tangkihndu tualah ena? & When will you climb the coconut tree? \\
\hline 32 & Ndigan kam reh? & When did you come? \\
\hline 33 & Ndigan danci ku pinjam senndu? & When can I borrow your money? \\
\hline 34 & Ndigan nge reh udan enda? & When the rain will come? \\
\hline 35 & Ndigan nge kena mulih ku kuta? & When you will go home? \\
\hline 36 & Ndigan nge reh bapak ndai mak? & When our father will come home? \\
\hline 37 & Ndigan nge rumah enda i bersihken? & When the house will be clean? \\
\hline 38 & Ndigan nge kena erlajar nakku? & When will you learn my son? \\
\hline 39 & Ndigan i dayaken durin enda? & When the durian will be sold? \\
\hline 40 & Ndigan kam jumpa ras temanndu? & When will you meet with your friend? \\
\hline 41 & Uga beritandu? & How are you? \\
\hline 42 & Uga beritana? & How are she? \\
\hline
\end{tabular}




\begin{tabular}{|c|c|c|}
\hline & & \\
\hline 43 & Uga kerja rani ndai? & How is thanksgiving? \\
\hline 44 & Uga maka danci bage? & How can be happened? \\
\hline 45 & Uga mpegeluh kreta enda? & How is to on this motorbike? \\
\hline 46 & Uga maka melas kulandu? & Why your body is fever? \\
\hline 47 & Uga maka meseng gulenndu ena? & Why your curry is burnt? \\
\hline 48 & Uga makana merawa nandendu? & Why your mother was angry? \\
\hline 49 & Uga mejinna kam e? & How ugly are you? \\
\hline 50. & Uga jilena kam e? & How beautiful are you? \\
\hline 51. & Ija kam tading? & Where do you live? \\
\hline 52. & Ija sen ku ndai? & Where is my money? \\
\hline 53. & Ija nge tukuren baju kebaya? & Where can buy a kebaya? \\
\hline 54. & Ija rumah Bapak ena? & Where is his house? \\
\hline 55. & Ija nge danci erlajar rende? & Who can teach me to sing? \\
\hline 56. & Ija nge tading ndeharana ena? & Where is her wife live? \\
\hline 57. & Ija nge tambarku ndai? & Where is my medicine? \\
\hline 58. & Ija ban kena bajuku si megara nake? & Where did you put my red cloth? \\
\hline 59. & Ija nge ingan man sintabehna? & Where can we find the best restaurant? \\
\hline 60. & Ija nge tading bulang ena? & Where is grandfather's living? \\
\hline 61. & Kai kin siterjadi? & What does happen? \\
\hline 62. & Kai ka kin enda? & What is going on? \\
\hline 63. & Kai makana kena mulih? & Why do you go home? \\
\hline 64. & Kai kin man cakapken? & What will we be talking about? \\
\hline 65. & Kai baju ta ku kerja pagi? & What will our uniform tomorrow? \\
\hline 66. & Kai kin sebabna makana jadi sibagenda? & What is the reason? \\
\hline 67. & Kai kin alasenndu? & What is your reason? \\
\hline 68. & Kai gealarna pangan si pan enda? & What is the food name that you eat? \\
\hline 69. & Kai kin maksudndu e? & What do your mean? \\
\hline
\end{tabular}




\begin{tabular}{|l|l|l|}
\hline & & \\
\hline 70. & Kai makana kena reh? & Why do you come? \\
\hline 71. & La kin kam si tading i Brastagi. & Don't you live in Brastagi. \\
\hline 72 & Jenda kin tading bibi si Beru Ginting. & Ginting's aunty living here. \\
\hline 73 & Ndube kena reh. & It's long tome you come here. \\
\hline 74 & Kurumah kena kari ya & Come to my home. \\
\hline 75. & Enda kin rumahndu. & It is your home. \\
\hline
\end{tabular}

Who, what, when, where, why, how were using in arrange the question sentences in the table. The table also availabel the yes and no question. For example La kin kena temanna? Don't you her/his friend? There were some question which did not use question mark or declarative sentence. For examples 1). La kin kam si tading i Brastagi. (Don't you live in Brastagi.). 2) Jenda kin tading bibi si Beru Ginting.( Ginting's aunty living here.) 3) Ndube kena reh.( It's long tome you come here.). 4) Kurumah kena kari ya. (Come to my home.) and Enda kin rumahndu. (It is your home.). The five number of the questions were shown the declarative sentences.

In Bahasa Karo to ask Who was not the same with English. For examples; Ise gelar diberu ena?

Ise gelardu?

(What is the girl's name?)

(What is your name?)

Karonese language do not use tobe or auxiliarry if the subject use adjective, adverb, and verb. The form of question in Karonese language direcly use subject and class of word.

\section{DISCUSSION}

To arrange the $X^{\prime}$ bar theory the researcher tried to make the Grammatical Pattern to make the sentences in question.

Table 2. Wh-Question in Karonese Language

\begin{tabular}{|l|l|l|}
\hline No. & $\begin{array}{l}\text { Wh-Question } \\
\text { In Karonese Language }\end{array}$ & $\begin{array}{l}\text { Grammatical Pattern Qestions in } \\
\text { Karonese Language }\end{array}$ \\
\hline 1. & $\begin{array}{l}\text { Ise dilaki si make baju } \\
\text { megara ah? } \\
\text { Ise gelar diberu ena? }\end{array}$ & Wh-Q + NP + VP + C \\
\hline 2. & Wh-Q + NP + C \\
\hline 3. & Ise si pang ngelawan Singa ena? & Wh-Q + VP + C \\
\hline 4. & Ise si pegeluh lampu ena? & Wh-Q + VP + C \\
\hline 5. & Ise si nukur tipi enda? & Wh-Q + VP + C \\
\hline 6. & Ise si erdalan ras nande ndai? & Wh-Q + VP + NP + C \\
\hline 7. & Ise gelarndu? & Wh-Q + NP + C \\
\hline 8. & Ise temanndu ku jenda? & Wh-Q + NP + C \\
\hline 9. & Ise gelar nandendu? & Wh-Q + NP + C \\
\hline
\end{tabular}




\begin{tabular}{|c|c|c|}
\hline 10. & Ise si nokohi kam? & $\mathrm{Wh}-\mathrm{Q}+\mathrm{VP}+\mathrm{C}$ \\
\hline 11. & Ise sitading ndeher rumahndu ena kak? & $\mathrm{Wh}-\mathrm{Q}+\mathrm{NP}+\mathrm{C}+\mathrm{NP}$ \\
\hline 12. & Ise gundari si tading i jenda? & Wh-Q + C \\
\hline 13. & Ise gelar diberu si mejile ena? & $\mathrm{Wh}-\mathrm{Q}+\mathrm{NP}+\mathrm{C}$ \\
\hline 14. & Ise nge sipuna rumah mejile enda? & Wh-Q + NP + Adj.P \\
\hline 15. & Ise nge danci ngapuli kita? & $\mathrm{Wh}-\mathrm{Q}+\mathrm{NP}+\mathrm{C}$ \\
\hline 16. & $\begin{array}{l}\text { Ise si jadi pemenang na } i \text { bas pertandingen } \\
\text { ndai? }\end{array}$ & Wh-Q + NP + Adj.P + C \\
\hline 17. & Ise ena nak ku? & Wh-Q + NP \\
\hline 18. & Sora ise ena? & $\mathrm{Wh}-\mathrm{Q}+\mathrm{AP}+\mathrm{C}$ \\
\hline 19. & Ise si danci nampati aku enda nake? & $\mathrm{Wh}-\mathrm{Q}+\mathrm{VP}+\mathrm{NP}+\mathrm{C}$ \\
\hline 20. & Ise si mbaru reh ena? & $\mathrm{Wh}-\mathrm{Q}+\mathrm{NP}+\mathrm{VP}+\mathrm{C}$ \\
\hline 21. & Ndigan kam mulih? & $\mathrm{Wh}-\mathrm{Q}+\mathrm{NP}+\mathrm{C}$ \\
\hline 22. & Ndigan kam reh? & $\mathrm{Wh}-\mathrm{Q}+\mathrm{NP}+\mathrm{C}$ \\
\hline 23. & Ndigan kam sereh? & $\mathrm{Wh}-\mathrm{Q}+\mathrm{NP}+\mathrm{C}$ \\
\hline 24. & Ndigan ia empo? & $\mathrm{Wh}-\mathrm{Q}+\mathrm{NP}+\mathrm{C}$ \\
\hline 25. & Ndigan ia pasu-pasu? & $\mathrm{Wh}-\mathrm{Q}+\mathrm{NP}+\mathrm{C}$ \\
\hline 26. & Ndigan kam lawes? & $\mathrm{Wh}-\mathrm{Q}+\mathrm{NP}+\mathrm{C}$ \\
\hline 27. & Ndigan tasakken gulen ena? & $\mathrm{Wh}-\mathrm{Q}+\mathrm{VP}+\mathrm{NP}+\mathrm{C}$ \\
\hline 28. & Ndigan kerja tahun kutandu? & $\mathrm{Wh}-\mathrm{Q}+\mathrm{NP}+\mathrm{C}$ \\
\hline 29. & Ndigan nge buniken Bp. Sope ndai? & $\mathrm{Wh}-\mathrm{Q}+\mathrm{VP}+\mathrm{NP}+\mathrm{C}$ \\
\hline 30. & Ndigan i benai acara enda? & Wh-Q + NP + Adj.P + C \\
\hline 31. & Ndigan tangkihndu tualah ena? & $\mathrm{Wh}-\mathrm{Q}+\mathrm{VP}+\mathrm{NP}+\mathrm{C}$ \\
\hline 32. & Ndigan kam reh? & $\mathrm{Wh}-\mathrm{Q}+\mathrm{NP}+\mathrm{C}$ \\
\hline 33. & Ndigan danci ku pinjam senndu? & $\mathrm{Wh}-\mathrm{Q}+\mathrm{VP}+\mathrm{NP}+\mathrm{C}$ \\
\hline 41. & Uga beritandu? & Wh-Q + NP? \\
\hline 42. & Uga beritana? & Wh-Q + NP? \\
\hline 43. & Uga kerja rani ndai? & Wh-Q + NP? \\
\hline 44. & Uga maka danci bage? & Wh-Q + NP? \\
\hline 45. & Uga mpegeluh kreta enda? & Wh-Q + NP? \\
\hline 46. & Ija kam tading? & Wh-Q + NP? \\
\hline 47. & Ija sen ku ndai? & Wh-Q + NP? \\
\hline 48. & Ija nge tukuren baju kebaya? & Wh-Q + NP? \\
\hline 49. & Ija rumah Bapak ena? & Wh-Q + NP? \\
\hline 50. & Ija nge danci erlajar rende? & Wh-Q + NP? \\
\hline 51. & Kai kin siterjadi? & Wh-Q + NP? \\
\hline 52. & Kai ka kin enda? & Wh-Q + NP? \\
\hline 53. & Kai makana kena mulih? & Wh-Q + NP? \\
\hline 54. & Kai kin man cakapken? & Wh-Q + NP? \\
\hline 55. & Kai baju ta ku kerja pagi? & Wh-Q + NP? \\
\hline 56. & La kin kam si tading i Brastagi. & $\mathrm{Aux}+\mathrm{NP}+\mathrm{PP}+\mathrm{C}$. \\
\hline 57. & Jenda kin tading bibi si Beru Ginting. & $\mathrm{Aux}+\mathrm{C}+\mathrm{NP}$ \\
\hline
\end{tabular}




\begin{tabular}{|l|l|l|}
\hline 58. & Ndube kena reh. & $\mathrm{C}+\mathrm{NP}$ \\
\hline 59. & Kurumah kena kari ya & $\mathrm{C}+\mathrm{NP}$ \\
\hline 60. & Enda kin rumahndu. & $\mathrm{Aux}+\mathrm{NP}$ \\
\hline 61. & Reh kam kari ya & $\mathrm{VP}+\mathrm{NP}$ \\
\hline
\end{tabular}

From the table showed that the dominant questions sentences in Karonese use; Wh-Q + NP?. It wrriten 15 times sentences in question. The second position was Wh-Q + NP + C. There were 12 times written in questions in Karonese Language. If they were compare between Karonese and English language so the grammar patern in question would diferent. Most Karonese language use auxiliary verb, but there were not based on time. It meant that Karonese language did not have tenses to mention something. The pattern was same in present, past and future. In Karonese language was found that question that was asking something but did not use question patern. Examples;

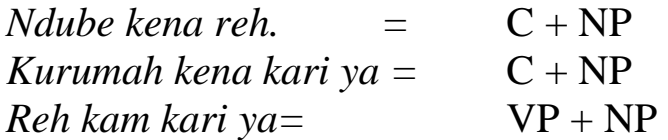

English has tenses to mention something. It would be different auxiliary when the time in present, past and future. The second was found that most English questions has the same formula when ask something. The formula used Wh-Q + Aux $+\mathrm{S}+\mathrm{V}+\mathrm{C}$ ? (see table 1)

\section{CONCLUSION}

The question sentences in Karonese Language is constructed by Wh-Question, Noun Phrase, Verb Phrase and Complement. It depens on the position is sentences if the yes and no question the question sentences do not need Wh-Q. The second found that there is no same pattern to arrange sentences in Karonese language. Karonese language do not use auxiliary in tenses to arrange the questions in a sentences. It also find that there is question sentence that do not use question patern. For example; Reh kam kari ya = VP + NP. The question sentences in English is constructed by WhQuestion, Auxiliary, Subject that can be use as NP, Verb that can be use as VP and Complement. The auxiliary is based on time. So there will different auxiliary when the time in present, past and future (It showed in tabel 1). In English also find the same patern in asking something but do not use question patern. For example; I will be waiting for you $=\mathrm{NP}+\mathrm{VP}+\mathrm{C}$. To ask the patern usually with the condition. That condition shows that the her loving waiting for the coming of her boy.

\section{ACKNOWLEDGEMENTS}

First of all, the writer would like to thank almighty Lord for His compassion and blessing given to the writer to finish this article. The very special gratitude is for Dr. Mulyadi, M.Hum., as her supervisor for his kindness, knowledge, patience, and motivation for the writer in writing this article.

\section{REFERENCES}

Al Aqad Mohammed. 2013. Syntactic analysis of Arabic adverb's between Arabic and English: X Bar Theory. International Journal of Language and Linguistic. Vol. 1, No. 3, 2013, pp. 70-74. doi: 10.11648/j.ijl 1.20130103.11

Fitriyani Zelina Dian dan Mulyadi. 2017. Interogative Sentence in Minagkabau Language: XBar Theory. RETORIKA: Jurnal Ilmu Bahasa Volume 3 Nomor 1. April 2017. 
Haegeman, Liliane.1992. Introduction to Government and Binding Theory. National Library Australia. Blackwell. UK.

Newson Mark. 2006. Basic English Syntax with Exercises. Bölcsész Konzorcium HEFOP Iroda

Revita, I. 2007. Permintaan dalam Bahasa dalam Minagkabau. Yogjakarta. Humaniora Vol 19. No. 2 Juni 2017. 